\title{
How Denationalization Divides Elites and Citizens
}

\section{Céline Teney*}

Universität Bremen, Zentrum für Sozialpolitik, Postfach 330440, 28334 Bremen, Germany; WZB Berlin Social Science Center. celine.teney@uni-bremen.de

\section{Marc Helbling}

WZB Berlin Social Science Center, Reichpietschufer 50, 10785 Berlin, Germany.

marc.helbling@wzb.eu

\begin{abstract}
Summary: Based on a unique survey among members of top level elites in eleven fields of activity in Germany, we investigate (1) elite-mass opinion incongruence and (2) the polarization of elites' positions on four contested denationalization issues. Our results show that the elite-mass attitudinal gap is significant for items directly tapping support for the further opening up of national borders, even when controlling for education, age, gender, place of residence, and political orientation. By contrast, elites across different fields of activity hold rather consensual positions on the issues of denationalization explored in the survey. Transnational networking and transnational mobility are not significantly associated with attitudes toward these issues. Elites with a strong supranational identity are significantly more strongly in favor of opening up borders to immigrants and increasing aid to developing countries.
\end{abstract}

Keywords: Elites; Globalization; Transnationalism; Attitudes; Social Cleavage; Germany.

Zusammenfassung: Auf der Grundlage einer einmaligen Befragung von Eliten in Top-Positionen in elf Tätigkeitsfeldern erforschen wir (1) Inkongruenzen von Meinungen zwischen den Eliten und der Bevölkerung und (2) die Polarisierung von Eliten-Positionen zu vier umstrittenen Denationalisierungs-Themen. Unsere Ergebnisse zeigen, dass die Kluft zwischen den Eliten und der Bevölkerung in jenen Fragen signifikant ausfällt, die in einem direkten Zusammenhang mit der weiteren Öffnung nationaler Grenzen stehen. Dieser Zusammenhang bleibt auch dann bestehen, wenn wir auf Bildung, Alter, Geschlecht, Wohnsitz und politische Orientierung kontrollieren. Im Gegensatz dazu nehmen Eliten, unabhängig von ihren Tätigkeitsfeldern, vergleichsweise einvernehmliche Positionen zu Fragen der Denationalisierung ein. Transnationale Aktivitäten und Mobilität stehen in keinem signifikanten Zusammenhang mit Einstellungen zu den vier untersuchten Themen. Eliten mit einer stark ausgeprägten supranationalen Identität sprechen sich allerdings deutlich häufiger dafür aus, die Grenzen für Einwanderer zu öffnen und die Entwicklungszusammenarbeit zu intensivieren.

Schlagwörter: Eliten; Globalisierung; Transnationalismus; Einstellungen; Soziale Spaltung; Deutschland.

\section{Introduction}

The lack of opinion congruence between elites and citizens and its potential implications for the quality of democracies have long been a crucial issue in the social sciences. This issue recently gained more attention from the scientific community since, as a result of growing economic, political and cultural globalization pressures, the divide between political

\footnotetext{
* We would like to thank Ruud Koopmans, Bernhard Weßels, Pieter de Wilde, the participants of the colloquium of the Migration and Diversity research unit at the WZB Social Science Center in Berlin, as well as the reviewers and editors of Zeitschrift für Soziologie for their helpful suggestions on earlier versions of this paper. We are grateful to Jutta Allmendinger, Elisabeth Bunselmeyer, Marc Holland-Cunz and Katrin Dribbisch for having organized the German elite survey.
}

elites and the general population seems to have become more severe. This elite-mass divide is argued to be one of the sources of citizens' increasing disaffection with the political debate (Crouch 2004), as well as for the increasing success of populist radical right parties in Europe (Ignazi 1992; Mudde 2004). Evidence for this elite-mass gap in traditional-libertarian opinions and values has been observed in various democracies (see, for example, Holsti 2004; Kaina 1997; McAllister 1991). According to these studies, elites hold significantly more liberal positions than the general population on issues such as environmental protection, gender equality, law enforcement, or postmaterialist values.

Beyond such differences in traditional-libertarian attitudes, various studies have recently been focusing on the lack of elite-mass opinion congruence on the process of European integration. The failed 
French and Dutch referenda on the EU constitution in 2005 indeed indicated that the general population was far less supportive of the EU project than their political representatives. This, in turn, has motivated the launch of a research agenda on the elitemass opinion incongruence regarding European integration. These studies have all come to similar conclusions: Whereas most European elites largely support the EU project, a large part of the general population remains skeptical about further European integration (Best et al. 2012; Flockhart 2005; Hooghe 2003; Mattila \& Raunio 2006; Steenbergen et al. 2007).

In this article, we investigate the extent to which the polarization of elites and the general population on European integration is part of a more general elite-mass divide. This gap encompasses issues of denationalization, that is, the opening up of national borders for a variety of international exchanges and interactions (Zürn 1998). Indeed, denationalization issues such as European integration or the opening up of borders to immigrants are polarizing western societies along new conflict lines (Azmanova 2011; Kriesi et al. 2012; Kriesi et al. 2008). For Azmanova (2011), the ideological poles of traditionalism-libertarianism are evolving into a cosmopolitanism-sovereigntism division due to disparities in the normative evaluation of the permeability of national borders. She claims that, because of globalization, an "opportunity-risks cleavage" is emerging among citizens. This cleavage crosscuts the traditional left-right axis and encompasses, on one side, cosmopolitan and open economic positions and, on the other, sovereigntist and closed economic positions. Accordingly, denationalization issues polarize the population into groups of winners and losers that do not necessarily follow classical social class divisions. Individuals holding a leading position in society are assumed to represent the ideal type of winners of globalization: they are highly likely to perceive globalization as an opportunity and thus support further integration into the global system. By contrast, individuals in insecure socio-economic positions are expected to think of globalization as putting their economic security at risk and thus to oppose the opening up of borders (Teney et al. 2013). Such a new conflict line due to globalization pressures would lead to a larger salience of the elite-mass divide on denationalization issues.

In this article we want to assess this elite-mass divide on four contested denationalization issues: immigration, international trade, development aid, and supranational political institutions. These is- sues refer to the opening up of national borders to people, goods, economic redistribution, and political authority. Moreover, we will investigate the extent to which positional elites of various fields of activity are polarized on these issues. Lastly, we will study the role of elites' transnational practices and supranational identification in dividing elites on these denationalization issues. Our study broadens the scope of previous findings in two ways. Firstly, we take into account elites from a large range of relevant fields of activity. This will enable us to test the generalizability of findings from previous studies, which mainly focused on national political elites in several European countries. Secondly, we will analyze the positions of elites and the general population not only on European integration, as others have done (e. g., Best et al. 2012; Hooghe 2003), but also on four main contested denationalization issues (i.e., immigration, international trade, supranational political institutions and development aid). This will enable us to assess whether the polarization on European integration is part of a broader divide that encompasses various issues dealing with the opening up of national borders.

We thus investigate the power of denationalization in polarizing elites and citizens along a new conflict line. The study is based on the analysis of attitudinal items from a face-to-face survey carried out among the top positional elites in eleven fields of activity in Germany (Bunselmeyer et al. 2013) and on the corresponding items available in mass survey data such as the European Social Survey or the World Value Survey. Before presenting the data used in this paper, we will first discuss potential explanations for an elite-mass divide and for polarization among elites. The results section is divided into two parts: firstly, we will present the results concerning the elite-mass attitudinal divide; secondly, we will investigate the extent to which various characteristics contribute to the polarization of elites on denationalization. In conclusion, we will discuss our findings.

\section{The Elite-Mass Divide}

The first research question of our study concerns the extent to which denationalization polarizes elites and the general population along a new conflict line. So far, the elite-mass attitudinal incongruence on European integration has received most of the attention of the European scientific community. For instance, it has been argued that political elites 
have been pushing the European integration process in a vacuum of public support (Steenbergen et al. 2007). In our study, by contrast, we will assess whether the elite-mass gap in the support of European integration is part of a broader societal conflict encompassing a wide range of contested denationalization issues.

Two main explanations for elite-mass opinion incongruence have been put forward in the literature. The first one refers to education differences: elites are on average more highly educated than the general population (McAllister 1991). Since education is a key factor in shaping liberal and progressive political opinions, such an educational gap could explain this elite-mass opinion incongruence. Previous studies have indeed shown that elites hold on average more liberal and progressive positions than the general population (e.g., Holsti 2004; McClosky \& Brill 1983). However, evidence points to the fact that elites hold significantly more liberal attitudes than other highly educated citizens (McAllister 1991). Thus, even if education plays an important role in the endorsement of liberal opinions, it cannot entirely account for opinion differences between leaders and the general population. This leads us to the second potential explanation for the elite-mass opinion incongruence: elites have been the main driving actors behind denationalization processes. They now have to share and defend the dominant ideology in Western Europe, such as liberal norms and values (Schimmelfennig 2001). In the age of globalization, this liberal ideology shared by Western European leaders has been transformed to encompass denationalization issues such as European enlargement (Schimmelfennig 2001) or moral obligations beyond the nation state, such as cosmopolitanism (Calhoun 2003; Helbling \& Teney 2014).

Socialization processes among the elites explain why they are relatively unified in defending denationalization processes. According to Putnam (1976), personal interactions among elites might be the main reason behind their shared values. Networks of personal (both formal and informal) communication and friendships help create value and opinion consensus. These personal interactions are usually not restricted to other influential persons within the same institutions but also encompass elites from other fields. These interactions are based on mutual trust and solidarity and they are facilitated by the homogeneity of the elite group in terms of educational and social backgrounds, recruitment patterns, or ideological affinities (Putnam 1976). These bonding interactions lead to a mutual cueing effect among elites. This would explain why elites are highly homogeneous in terms of values and beliefs representing a dominant ideology, and why the elite-mass gap cannot be explained by educational differences alone. Recent empirical evidence for such an intra-elites mutual cueing effect regarding European integration has been provided by Müller et al. (2012), who showed that the agreement between business and political elites in their positions on European integration issues is much larger than between political elites and their voters.

We therefore hypothesize elites to support denationalization to a much larger extent than citizens, even when accounting for education differences (H1). This hypothesis will be tested by taking into account gender, age, and place of residence since these socio-demographic characteristics have been shown to contribute to the polarization of the general population into groups of winners and losers of globalization (Kriesi et al. 2012). Moreover, we will test this hypothesis by controlling for the leftright self-placement scale because positions on contested denationalization issues such as immigration, trade, development aid, and supranational political institutions are closely linked to personal political orientation.

\section{Polarization among Elites}

Even if elites tend to represent the overall dominant ideology, such as liberalism and its potential extension to denationalization issues, this does not necessarily imply that all elites have the same opinion on denationalization: while we expect large opinion incongruence between elites and the general population, denationalization issues might also polarize elites. Polarization among elites is nevertheless expected to be smaller than the elite-mass gap. Two main factors might account for such polarization.

First of all, elites might hold conflicting opinions on denationalization issues depending on their fields of activity. According to the postrecruitment socialization hypothesis (Putnam 1976), elites' opinions reflect the interests of the positions and institutions they represent; thus they might hold divergent or conflicting positions (see also McClosky \& Brill 1983). The recruitment patterns in their field of activity (e.g., apprenticeships) and the function held by elites are assumed to shape their opinions (Putnam 1976). This postrecruitment socialization is expected to build a certain degree of cohesion among leaders within institutions (see Suvarierol 2011 for the case of the EU commission). It 
would also imply that elites working in institutions or fields with conflicting interests would hold divergent opinions compared to elites representing institutions with overlapping interests. Evidence of the postrecruitment hypothesis for denationalization issues so far has been inconclusive. Best et al. (2012) show that both political and business elites in European countries strongly favor European integration and speak of an intra-elites mutual cueing effect on the European integration issue, arguing that national elites from different fields form elite systems that are closely attuned concerning European integration (Best et al. 2012). By contrast, Holsti (2004) highlights that US leaders from fields of activity with conflicting interests differ significantly in their support for financial redistribution across borders: business executives and members of Congress express less support for development aid than leaders of the media, academic, church, and labor unions (Holsti 2004). According to the postrecruitment hypothesis, elites would represent in their personal positions to some extent the positions and interests of their respective fields, even when accounting for their personal political orientation. More precisely, we would expect elites belonging to fields that have traditionally been on the left side of the political spectrum (such as the labor union and civil society fields) to be more supportive support of development aid and the opening up of national borders to immigrants than the other elites. By contrast, we would expect elites from these traditionally leftist fields to more strongly oppose the opening up of borders to international trade than elites from other fields. With regard to the field traditionally on the right side of the political spectrum-that is, the economic one-, we would expect the inverse association: business elites would tend to support international trade to a larger extent but immigration and development aid to a lesser extent than the other elites.

However, we do not expect significant field-based differences among elites on the issue of supranational political institutions. Indeed, it has been shown that actors on both (non-radical) left and right sides of the political spectrum support the further integration of the EU (Hooghe et al. 2004). Lastly, we would expect political elites to hold positions that are closest to public opinion: since voters are the "clients" of political leaders, we expect them to oppose denationalization to a larger extent than other elites. We will test the postrecruitment hypothesis by controlling for gender, age, education, place of birth, and the personal left-right political orientation, as these characteristics might also contribute to the polarization of elites along the new conflict line. All in all, our postrecruitment hypothesis states that the fields of activity have a significant polarizing effect among elites on international trade, immigration and development aid issues, even when controlling for gender, education, age, and political orientation. Sector-based differences are not significant on the issue of supranational political institutions $(\mathrm{H} 2)$.

The second factor that might contribute to the polarization of elites on denationalization issues is the increasing internationalization of a part of the elites. Indeed, the weakening of nation-state boundaries has greatly facilitated transnational contacts and interactions among citizens. These actions may involve the crossing of nation-state borders either physically, in the form of frequent traveling (Calhoun 2002), or virtually in the form of communicating with others abroad (Norris \& Inglehart 2009). Besides transnational interactions, the loosening of national boundaries enables the emergence of a sense of belonging to a supranational community. Several studies have shown that transnational interactions and supranational identification are associated with support for the opening up of national borders among the general population (Diez Medrano 2010; Fligstein 2008; Gustafson 2009; Jackman \& Vavreck 2011; Mau et al. 2008; Pichler 2012; see also Helbling \&Teney 2014).

In contrast to the previous hypotheses based on the sociology of the elites, we derive our two last hypotheses from theoretical explanations on the role of transnational practices and supranational identities in shaping public opinion. Indeed, so far studies on elites have neglected the role of growing internationalization among elites in polarizing their attitudes. This comes somewhat as a surprise since globalization has been considered an elite-driven process. To our best knowledge, Best (2012) is the only one so far to have investigated this question with respect to national political and economic elites in several European countries and their positions on European integration. He found that the link between contacts with European institutions and support for further European integration was significantly positive among political elites but remained insignificant among business elites. Moreover, the association of expatriate experience with support for further European integration was insignificant for both political and business elites (Best 2012). In contrast to the sparse findings on the role of transnational practices in shaping elites' positions, studies among the general population have consistently shown significant associations between 
transnational practices and supranational identification on the one hand and support for several denationalization issues on the other. For instance, transnational practices are positively associated with support for European integration (Kuhn 2011), global governance (Mau et al. 2008), or favorable attitudes toward immigrants (Mau et al. 2008). In addition, supranational identification has been shown to be positively related to support for European integration (Fligstein 2008; Teney et al. 2013) and to tolerance toward immigrants (Phillips 2002; Pichler 2009b; Pichler 2012; Teney et al 2013). These positive associations of transnational practices and supranational identity with the support for the opening up of national borders are likely to be present among elites as well. Indeed, transnational mobility and networking are mainly practiced by highly privileged citizens who possess the necessary resources to engage in transnational experiences (e.g., foreign language skills, high education; cf. Diez Medrano 2010; Fligstein 2008). Similarly, the sense of belonging to a supranational community is more developed among highly skilled and educated citizens (Pichler 2012). Transnational interactions and a supranational sense of belonging can thus act as new status markers (Kendall et al. 2009) and contribute to the further polarization of the population along the new conflict line (Diez Medrano 2010).

Therefore, an unequal distribution of transnational practices and a supranational sense of belonging among elites is likely to contribute to a further polarization of elites on denationalization issues. We will thus assess the power of transnational interactions and supranational sense of belonging in polarizing elites along such new conflict lines. We expect elites with high levels of transnational practices (H3) and with a supranational identity (H4) to be more supportive of denationalization issues.

\section{Data}

The data on the attitudes and positions of elites come from a face-to-face survey with highly standardized questionnaires that was carried out in 2011/2012 among 354 members of elites holding the highest positions in eleven fields of activity in Germany. This elite survey is based on a sampling design of positional elites: accordingly, elites are defined as "incumbents of leadership positions in powerful political institutions and private organizations who, by virtue of their control of intra-organizational power resources, are able to influence im- portant (political) decisions" (Hoffmann-Lange 2008: 53). This positional approach requires a twostep sampling procedure: first, one selects the highest organizations for each field; then one selects the highest positions within these organizations (Hoffmann-Lange 1992: 86-90). The selection of the most important organizations within a field is based on a consistent criterion, such as sale volumes of companies or market share of newspapers (Machatzke 1997). This field-based sampling design of positional elites is a replication of the design used in the 1995 Potsdam elite survey (Bürklin \& Rebenstorf 1997), which is the most recent comprehensive elite survey using conventional survey research methods carried out in Germany. However, in contrast to the 1995 Potsdam elite survey, which included a broader sample of elites, the WZB elite survey encompasses only the core elites: the original sample included 956 top positional elites in eleven fields of activity (Bunselmeyer et al. 2013). The survey response rate was 37 percent, which can be considered high, ${ }^{1}$ considering the difficulties of surveying this very privileged population (HoffmannLange 2008).

The data are composed of the responses of 354 top elites holding the highest positions in the fields of business and finance, professional lobbyists, politics, bureaucracy, military, research, media, labor union, law, church, and civil society (Bunselmeyer et al. 2013). For the field of business and finance, 103 CEOs and members of the supervisory boards of the 100 largest German companies took part in the survey (which represents a response rate of 25.9 percent in this field). Six presidents and vice presidents from the three largest business lobbyists make up the professional lobbyist subsample (response rate of 60 percent for this subsample). 29 political elites working in the Bundestag, the federal and state governments, and other institutions answered the questionnaire (response rate of 22 percent). The bureaucracy subsample is composed of 93 civil servants, including the state secretaries and directors of the federal ministries (response rate of 57.8 percent). Nine military leaders, such as the chiefs of staff of various commandos and forces, took part in the survey (response rate of 45 percent for the field of the military. In the field of research (response rate of 76.9 percent), 40 presidents and vice presidents of the largest research organizations and the conference of the university

\footnotetext{
${ }^{1}$ By comparison, the German telephone survey of MPs and business elites, carried out in 2007 by Best et al. (2012), had a response rate of 13.7 percent.
} 
presidents participated in the survey. Ten program directors, editors-in-chief and directors of state and private television channels and of the largest national newspapers constitute the media subsample (response rate of 22.2 percent). Thirteen presidents of the largest labor unions and 29 presidents, vicepresidents and prosecutors of the federal courts make up the labor union (response rate of 76.5 percent) and law (35.8 percent) subsamples, respectively. With regard to the field of the churches (response rate of 40 percent), 6 archbishops of the Catholic Church and the synod members of the Protestant Church in Germany took part in the survey. Lastly, 16 presidents of the largest civil society associations, such as the largest welfare federations or the cultural council, make up the civil society subsample (response rate of 64 percent). The size of the subsamples varies across fields, with the business and bureaucracy fields being the largest ones. These unequal sample sizes across the eleven fields result from the decision to overweight some subsamples (such as the economic field) as well as from the variation in the effective response rates in each of the eleven fields.

This elite survey aimed at collecting precise sociodemographic characteristics and at measuring elites' positions and attitudes toward various relevant domestic and international policy issues. The questionnaire contained several closed questions on immigration, supranational political institutions (EU and UN), international trade and development aid. The phrasing of these questions matches the item wordings from general mass surveys. This questionnaire design allows us to compare the attitudes of German elites toward these denationalization issues with the attitudes of the general German population. The mass surveys containing the corresponding items are the following ones: the World Value Survey (WVS, 2006, N=2064), the European Social Survey (ESS, 2010, $\mathrm{N}=3031$ ), the Transatlantic Trend Survey (TTS, 2009, N = 1000) and the WZB denationalization survey (WZB, 2007, N = 1503; Ecker-Ehrhardt et al. 2008). Thus, depending on the items, the time gap between the elite survey and the mass surveys ranges from two to five years.

\subsection{Dependent Variables}

We will test our hypotheses with two distinct analyses. Firstly, we will assess the elite-mass attitudinal gap by combining the elite data with the mass survey data containing the corresponding items. Secondly, we will investigate a potential polarization within the elites by running stepwise OLS regressions on the elite data alone. The items measuring positions toward denationalization issues among the general population come from four different mass surveys. We need therefore to analyze each item separately and cannot build indexes summarizing the items for each of the four denationalization issues. In total the analysis of the elite-mass gap is based on eight different items: three items measure attitudes toward immigration, one refers to international trade, two measure attitudes toward development aid, and two refer to respondents' satisfaction with two supranational political regimes (the EU and the UN). The exact wording of these items and their distribution among elites and the general population can be found in the online appendix to this paper (www.zfs-online.org). We recoded these items so that they all range from 0 to 1 , where 1 refers to the largest support for opening up national borders.

In the second part of our analysis, we will investigate elite polarization on the four denationalization issues by focusing on the elite data. We will use the items presented in Table A1 (online appendix) in the analysis. The sets of items measuring attitudes to immigrants, to development aid and to international trade are unidimensional. They were therefore summed up to build additive scales. All variables range from 0 to 1 , where 1 refers to the largest support for opening up national borders. We analyze the following dependent variables: opening up borders to immigrants, favoring larger funding for development aid, supporting international trade, satisfaction with the work of the EU and satisfaction with the work of the UN. The descriptive statistics concerning these scales can be found in Table A2 (online appendix).

\subsection{Independent Variables}

We will analyze the elite-mass gap by controlling for gender, age (centered around its mean), tertiary education, the left-right self-placement scale ("RILE," centered around its mean), and whether respondents are from East Germany. All except the last characteristic are coded in exactly the same way in both the elite and mass data. The dummy "East Germany" refers to the place of residence among the general population and to the place of birth among the elites, as the two surveys did not include the same questions. The descriptive statistics for the independent variables are presented in Table A2. 
In the second part of the analysis, we will use additional characteristics from the elite data. Firstly, we will investigate the role of the fields of activity in polarizing elites along the five dependent variables. In order to have sufficient cases per field of activity, we regrouped the elites into seven generic categories: business (composed of the professional lobbyism and business fields, $\mathrm{n}=109$ ), civil society (composed of the church, media and civil society fields, $n=32)$, labor union $(n=13)$, politics $(n=29)$, bureaucracy (composed of the administration and military fields, $n=102)$, law $(n=29)$ and research $(n=40)$. Secondly, the transnationalization of elites is measured with two variables. "Expatriate experience" is a dummy differentiating elites who stayed at least three months abroad. "Transnational contacts" is a composite index composed of the sum of contacts with people living abroad and the frequency of these transnational contacts. The sum of elites' contacts with people living abroad is an ordinal variable ranging from none $(11 \%), 1$ to 5 (20\%), 6 to $10(18.4 \%), 11$ to $25(21.6 \%), 26$ to $75(19.3 \%)$ and more than $75(9.7 \%)$. The variable measuring the frequency of transnational contacts is composed of a 5-point-Likert-scale ranging from "never" to "at least once a day." On average, elites have transnational contacts at least once a month. We summed up these two variables to build an additive index, to which both variables contribute equally. The transnational contact scale ranges from 0 to 1 , where a high value means many frequent contacts with people from abroad. Lastly, the supranational identification variable is an additive scale composed of items measuring the degree of identification with the local community, Germany, the EU, and the world. These four items are unidimensional and form a Mokken scale (Loevinger's $H$ coefficient: 0.55 for the entire scale) in which the world identification item followed by the EU identification item are the least popular ones. ${ }^{2}$ We can therefore build a cumulative scale by summing up the items (Molenaar \& Sijtsma 2000). This scale

\footnotetext{
2 The unidimensionality of this set of identification variables among elites sharply contrasts with the bidimensionality of these identification variables among the general population. Various studies have indeed shown that supranational identification is independent of national identification among the general population (e.g., Hanquinet \& Savage 2012; Pichler 2009a; Teney et al. 2013). Our results shed light on a further potential elite-mass gap related to the relationships between national and supranational identifications. However, the further investigation of this elite-mass divide on supranational identification is beyond the scope of our article.
}

ranges from 0 to 1 , where a high value means a strong supranational identity.

\section{Results}

\subsection{Elite-mass Divide}

Table 1 presents the results of OLS linear regressions on the eight items measuring the four denationalization issues. These regressions are based on the combined mass and elite data. For three out of the four denationalization issues, elites support the opening up of borders to a significantly larger extent than the general population: the regression coefficient for the elite dummy is significantly positive on the three immigration items, on the trade item, and on the two development aid items. In other words, there are significant elite-mass positional discrepancies on the issues of immigration, international trade, and development aid that cannot be explained by elite-mass differences in education, age, gender, place of residence, and political orientation. Indeed, while the coefficients for tertiary education, age, political orientation, and, to a lesser extent, for East Germany do exert a significant influence on these six attitudinal items, they cannot entirely account for elite-mass opinion incongruence. However, these results cannot be generalized for the four denationalization issues: elites are significantly more critical of the work of the EU and UN than the general population. Our results show indeed that the general population is significantly more satisfied with their work of the EU and UN than the elites. However, these results on supranational political institutions should be interpreted with caution: while these items refer to a denationalization issue, their exact wording does not directly measure attitudes toward the opening up of national borders. The items on supranational political institutions do not directly refer to support for and opposition to the principle of EU and UN integration but evaluate the work of these two supranational political regimes. Being critical of the polity is a form of Euroscepticism that is distinct from contesting the principle and project of integration (De Wilde \& Trenz 2012). These forms are not necessarily related: dissatisfaction with the work of the EU and UN is not necessarily correlated with the rejection of such supranational political bodies. Unfortunately, the elite survey does not contain any items measuring attitudes toward the principle and project of integration for the EU and the UN. Nevertheless, we know from previous studies that elites are far more supportive of European integration than the average citizen (e. g., Best et al. 2012). 
Table 1 Attitudes of the elites and the population on denationalization issues

\begin{tabular}{|c|c|c|c|c|}
\hline & $\begin{array}{c}\text { (WVS) } \\
\text { Immigration } 1\end{array}$ & $\begin{array}{c}\text { (WVS) } \\
\text { Immigration } 2\end{array}$ & $\begin{array}{c}\text { (ESS5) } \\
\text { Immigration } 3\end{array}$ & $\begin{array}{l}\text { (TTS09) } \\
\text { Trade }\end{array}$ \\
\hline Elite & $\begin{array}{l}0.167^{* * *} \\
(7.16)\end{array}$ & $\begin{array}{l}0.157^{* * *} \\
(8.14)\end{array}$ & $\begin{array}{l}0.223^{* * *} \\
(15.26)\end{array}$ & $\begin{array}{l}0.165^{* * *} \\
(7.71)\end{array}$ \\
\hline Women & $\begin{array}{l}-0.008 \\
(-0.64)\end{array}$ & $\begin{array}{l}0.020 \\
(1.85)\end{array}$ & $\begin{array}{l}-0.034 * * * \\
(-4.15)\end{array}$ & $\begin{array}{l}-0.072 * * * \\
(-5.21)\end{array}$ \\
\hline Tertiary education & $\begin{array}{l}0.050 * * \\
(2.77)\end{array}$ & $\begin{array}{l}0.123 * * * \\
(8.20)\end{array}$ & $\begin{array}{l}0.112 * * * \\
(12.28)\end{array}$ & $\begin{array}{l}-0.025 \\
(-1.31)\end{array}$ \\
\hline Age & $\begin{array}{l}-0.002 * * * \\
(-4.60)\end{array}$ & $\begin{array}{l}-0.001 * * \\
(-3.02)\end{array}$ & $\begin{array}{l}-0.001^{*} \\
(-2.28)\end{array}$ & $\begin{array}{l}0.002^{* * *} \\
(4.41)\end{array}$ \\
\hline East & $\begin{array}{l}-0.024 \\
(-1.85)\end{array}$ & $\begin{array}{l}-0.075 * * * \\
(-6.87)\end{array}$ & $\begin{array}{l}-0.083 * * * \\
(-9.49)\end{array}$ & $\begin{array}{l}-0.011 \\
(-0.61)\end{array}$ \\
\hline RILE & $\begin{array}{l}-0.012^{* * *} \\
(-5.15)\end{array}$ & $\begin{array}{l}-0.031^{* * *} \\
(-10.89)\end{array}$ & $\begin{array}{l}-0.013 * * * \\
(-5.52)\end{array}$ & $\begin{array}{l}0.010 * * \\
(3.11)\end{array}$ \\
\hline _cons & $\begin{array}{l}0.067^{* * *} \\
(5.59)\end{array}$ & $\begin{array}{l}0.546 * * * \\
(54.89)\end{array}$ & $\begin{array}{l}0.523^{* * *} \\
(74.09)\end{array}$ & $\begin{array}{l}0.787^{* * *} \\
(69.21)\end{array}$ \\
\hline $\begin{array}{l}N \\
\text { Adj. } R^{2}\end{array}$ & $\begin{array}{l}2044 \\
0.086\end{array}$ & $\begin{array}{l}2100 \\
0.215\end{array}$ & $\begin{array}{l}3080 \\
0.224\end{array}$ & $\begin{array}{l}1264 \\
0.159\end{array}$ \\
\hline & $\begin{array}{c}\text { (WVS) } \\
\text { Development aid } 1\end{array}$ & $\begin{array}{c}\text { (WVS) } \\
\text { Development aid } 2\end{array}$ & $\begin{array}{c}\text { (WZB) } \\
\text { EU satisfaction }\end{array}$ & $\begin{array}{c}\text { (WZB) } \\
\text { UN satisfaction }\end{array}$ \\
\hline Elite & $\begin{array}{l}0.109 * * \\
(2.90)\end{array}$ & $\begin{array}{l}0.273^{* * *} \\
(6.87)\end{array}$ & $\begin{array}{l}-0.0462^{*} \\
(-2.36)\end{array}$ & $\begin{array}{l}-0.119 * * * \\
(-6.53)\end{array}$ \\
\hline Women & $\begin{array}{l}-0.001 \\
(-0.04)\end{array}$ & $\begin{array}{l}-0.019 \\
(-0.86)\end{array}$ & $\begin{array}{c}0.010 \\
(0.82)\end{array}$ & $\begin{array}{c}0.018 \\
(1.60)\end{array}$ \\
\hline Tertiary education & $\begin{array}{l}0.165^{* * *} \\
(5.63)\end{array}$ & $\begin{array}{l}0.184^{* * *} \\
(6.01)\end{array}$ & $\begin{array}{c}0.022 \\
(1.29)\end{array}$ & $\begin{array}{c}0.018 \\
(1.15)\end{array}$ \\
\hline Age & $\begin{array}{l}-0.002^{*} \\
(-2.47)\end{array}$ & $\begin{array}{l}-0.001^{*} \\
(-2.13)\end{array}$ & $\begin{array}{l}-0.001 \\
(-1.93)\end{array}$ & $\begin{array}{l}-0.001^{*} \\
(-2.49)\end{array}$ \\
\hline East & $\begin{array}{l}-0.1722^{* * *} \\
(-8.10)\end{array}$ & $\begin{array}{l}-0.059 * * \\
(-2.58)\end{array}$ & $\begin{array}{l}-0.019 \\
(-1.28)\end{array}$ & $\begin{array}{l}-0.046^{* *} \\
(-3.21)\end{array}$ \\
\hline RILE & $\begin{array}{l}-0.047^{* * *} \\
(-8.47)\end{array}$ & $\begin{array}{l}-0.039 * * * \\
(-6.57)\end{array}$ & $\begin{array}{c}0.012 \\
(0.42)\end{array}$ & $\begin{array}{l}-0.011 \\
(-0.42)\end{array}$ \\
\hline _cons & $\begin{array}{l}0.322^{* * *} \\
(16.69)\end{array}$ & $\begin{array}{l}0.317^{* * *} \\
(15.51)\end{array}$ & $\begin{array}{l}0.560^{* * *} \\
(4.33)\end{array}$ & $\begin{array}{l}0.499 * * * \\
(4.13)\end{array}$ \\
\hline$N$ & 1990 & 1876 & 1733 & 1708 \\
\hline Adj. $R^{2}$ & 0.122 & 0.136 & 0.005 & 0.051 \\
\hline
\end{tabular}

Significances: ${ }^{*} \mathrm{p}<0.05,{ }^{*} \mathrm{p}<0.01,{ }^{* * *} \mathrm{p}<0.001$

Notes: OLS regressions, $t$ statistics in parentheses. The items have been recoded so that the highest value (1) means: Immigration 1: “The government should let anyone come who wants to"; Immigration 2: "Immigrants enrich life"; Immigration 3: "Immigration is good for the German economy"; Trade: "In times like these, it is important for Germany to remain open to international trade"; Development aid 1: "I am willing to pay higher taxes to increase aid to developing countries"; Development aid 2: "The amount allocated by Germany to development aid is too low"; EU Satisfaction: "I am completely satisfied with the work of the EU"; UN Satisfaction: "I am completely satisfied with the work of the UN." 
All in all, these results confirm our first hypothesis: the mass-elite attitudinal gap is significant for items directly tapping the support for further opening up national borders, even when controlling for the main socio-demographic characteristics such as education and political orientation.

\subsection{Polarization among Elites}

In the first regression models presented in Table 2, we introduced the fields of activity and the main socio-demographic characteristics (gender, age, education, place of birth). First of all, the socio-demographic characteristics do not have any constant effect on the dependent variables. Women are significantly more satisfied with the work of the UN and are significantly less in favor of international trade than men. Elites without tertiary education support international trade to a significantly lesser extent. Age is not significantly related to any of the four issues. Whether elites were born in the former GDR or abroad does not play any significant role in their positions on the four denationalization issues. By contrast, elites' political orientation is significantly associated with their opinions on immigration, development aid, and international trade but not with their satisfaction with the EU or the UN. Elites on the right side of the political scale are significantly less likely to support immigration and development aid and more likely to support international trade.

Next to the effects of socio-demographic characteristics and political orientation, this first model allows us to assess the extent to which elites are polarized on the four denationalization issues along their fields of activity. Regarding the first dependent variable, the fields of activity (controlled for education, age, gender, and place of birth) do not much affect elites' positions on the opening up of national borders for immigrants. ${ }^{3}$ Indeed, with the exception of labor union elites, elite attitudes toward immigration in the other fields are similar to those of the business elites. By contrast, elites working in the labor union field do support the opening up of national borders to immigrants to a significantly larger extent than business elites. This reflects the German labor unions' traditional support for the interests of immigrants and guest workers

\footnotetext{
${ }^{3}$ In all models we took the business elite as the reference category as they constitute the largest group and can be expected to be at one extreme of the left-right dimension. This makes it most probable to get significant results. Results do not change if we take another group as reference category.
}

(Kühne 2000). Likewise, elites are not much polarized along their fields of activity regarding their positions on development aid. Indeed, elites from the field of law are the only ones to be more supportive of higher taxes for development aid than business elites. International trade is the issue that most polarized elites along their fields of activity. While elites working in law and politics and business elites hold similar attitudes toward international trade, elites from the other fields of activity are significantly less likely to support international trade than business elites. These effects are moderate, however, since these coefficients are only significant at the 0.05 level. Lastly, the only field with a significant coefficient on the supranational political institutions items is the administrative one: administrative elites are significantly more satisfied with the EU than business elites. Besides the administrative elites, elites from the other fields are equally satisfied with the work of the EU and the UN.

In sum, and with the exception of their positions on international trade, elites are not significantly divided by their fields of activity when it comes to denationalization issues. Moreover, the coefficients for the various fields remain relatively small. This, in turn, supports our interpretation that the fields do not play an important role in the polarization of elites. This leads us to reject our second hypothesis: Sectors of activity do not have any strong polarizing effect among elites on denationalization issues when controlling for gender, education, age, place of birth, and political orientation. Furthermore, elites from fields with the largest conflicting interests with the business field do not differ greatly from the business elites in their positions on denationalization. Lastly, and contrary to our expectations, political elites do not oppose denationalization issues to a greater extent than the other elites. Whereas the general population is evenly divided on these denationalization issues (Table 1), political elites in their personal positions do not represent public opinion: in fact, they support denationalization to the same extent as non-representative elites. All in all, our results do not provide much supportive evidence for the postrecruitment hypothesis: once we control for education, age, gender, place of birth, and political orientation, elites from the various fields of activities share similar positions on denationalization.

Table 3 presents the results of the models including expatriate experience, transnational contacts, and supranational identification. The first model of Table 3 is composed of the expatriate dummy and the transnational contacts variable by controlling for the effects of the fields of activity, gender, age, 
Table 2 Effects of elite fields on denationalization

\begin{tabular}{|c|c|c|c|c|c|}
\hline & Immigrant Index & $\begin{array}{l}\text { Development } \\
\text { aid Index }\end{array}$ & Trade Index & $\begin{array}{l}\text { EU satisfaction } \\
\text { Item }\end{array}$ & $\begin{array}{l}\text { UN satisfaction } \\
\text { Item }\end{array}$ \\
\hline \multicolumn{6}{|l|}{ Model 1} \\
\hline \multicolumn{6}{|c|}{ Sector (ref: business) } \\
\hline \multirow[t]{2}{*}{ Civil society } & 0.040 & 0.122 & $-0.075^{*}$ & 0.011 & -0.029 \\
\hline & $(1.17)$ & $(1.82)$ & $(-2.37)$ & $(0.24)$ & $(-0.62)$ \\
\hline \multirow[t]{2}{*}{ Labor Union } & $0.129 *$ & 0.172 & $-0.099 *$ & -0.105 & 0.068 \\
\hline & $(2.31)$ & $(1.61)$ & $(-1.98)$ & $(-1.44)$ & $(0.96)$ \\
\hline \multirow[t]{2}{*}{ Law } & -0.020 & $0.138^{*}$ & -0.011 & 0.033 & 0.013 \\
\hline & $(-0.55)$ & $(2.06)$ & $(-0.34)$ & $(0.71)$ & $(0.28)$ \\
\hline \multirow[t]{2}{*}{ Politics } & 0.046 & 0.042 & -0.029 & 0.062 & 0.033 \\
\hline & $(1.17)$ & $(0.59)$ & $(-0.85)$ & $(1.21)$ & $(0.66)$ \\
\hline \multirow[t]{2}{*}{ Bureaucracy } & 0.010 & 0.023 & $-0.047^{*}$ & $0.092 * *$ & 0.005 \\
\hline & $(0.41)$ & $(0.51)$ & $(-2.15)$ & $(2.89)$ & $(0.16)$ \\
\hline \multirow[t]{2}{*}{ Research } & 0.028 & 0.099 & $-0.057^{*}$ & 0.027 & 0.070 \\
\hline & $(0.91)$ & $(1.78)$ & $(-2.02)$ & $(0.66)$ & $(1.75)$ \\
\hline \multirow[t]{2}{*}{ Female } & -0.003 & 0.013 & $-0.059 *$ & -0.019 & $0.083^{*}$ \\
\hline & $(-0.11)$ & $(0.23)$ & $(-2.22)$ & $(-0.51)$ & $(2.22)$ \\
\hline \multirow[t]{2}{*}{ Age } & -0.002 & -0.0002 & 0.001 & 0.003 & -0.001 \\
\hline & $(-1.64)$ & $(-0.07)$ & $(0.42)$ & $(1.73)$ & $(-0.56)$ \\
\hline \multirow[t]{2}{*}{ No tertiary degree } & 0.022 & -0.038 & $-0.063^{*}$ & 0.024 & -0.016 \\
\hline & $(0.65)$ & $(-0.61)$ & $(-2.15)$ & $(0.53)$ & $(-0.36)$ \\
\hline \multirow[t]{2}{*}{ East Germany } & 0.023 & -0.091 & 0.036 & -0.046 & -0.036 \\
\hline & $(0.38)$ & $(-0.89)$ & $(0.68)$ & $(-0.61)$ & $(-0.49)$ \\
\hline \multirow[t]{2}{*}{ Born abroad } & 0.017 & 0.062 & -0.023 & 0.104 & -0.113 \\
\hline & $(0.27)$ & $(0.61)$ & $(-0.43)$ & $(1.34)$ & $(-1.47)$ \\
\hline \multirow[t]{2}{*}{ Left-right } & $-0.013^{*}$ & $-0.066^{* * *}$ & $0.012^{*}$ & -0.013 & -0.017 \\
\hline & $(-1.97)$ & $(-5.35)$ & $(2.06)$ & $(-1.44)$ & $(-1.97)$ \\
\hline \multirow[t]{2}{*}{ _cons } & $0.842 * * *$ & $0.741 * * *$ & $0.825^{* * *}$ & $0.269^{*}$ & $0.482 * * *$ \\
\hline & (10.59) & $(4.98)$ & $(11.46)$ & $(2.55)$ & $(4.61)$ \\
\hline Adjusted $R^{2}$ & 0.043 & 0.1489 & 0.070 & 0.014 & 0.032 \\
\hline
\end{tabular}

Significances: ${ }^{*} p<0.05,{ }^{* *} p<0.01,{ }^{* * *} p<0.001, N=354$

Notes: OLS regressions, $\mathrm{t}$ statistics in parentheses.

education, place of birth and political orientation. In a last step, we added supranational identification to the models. Firstly, whether elites stayed abroad for at least three months is not significantly associated with their positions on any of the denationalization issues. Secondly, numerous and frequent transnational contacts are not significantly associated with any of the four issues. These results contradict our third hypothesis since transnational practices are not significantly associated with denationalization issues among elites.

In the last model, we included the supranational identification variable. Supranational identification is significantly and positively associated with two of the four issues: elites strongly identifying themselves as EU and world citizens are much more supportive of opening up national borders to immigrants and providing further funding for development aid. These results partly confirm our last hypothesis: Elites with a strong supranational identity are significantly more in favor of opening borders for immigrants and for increasing aid in developing countries. However, supranational identity is not significantly associated with attitudes toward international trade, and with satisfaction with the work of the EU and UN. 
Table 3 Effects of transnationalism and supranational identification on denationalization issues among elites

\begin{tabular}{lccccc}
\hline & Immigrants & $\begin{array}{c}\text { Development } \\
\text { aid }\end{array}$ & Trade & $\begin{array}{c}\text { EU } \\
\text { satisfaction }\end{array}$ & $\begin{array}{c}\text { UN } \\
\text { satisfaction }\end{array}$ \\
\hline Model 2 & & & & & \\
Expatriate experience & 0.010 & 0.007 & 0.019 & 0.002 & -0.0001 \\
& $(0.50)$ & $(0.19)$ & $(1.03)$ & $(0.06)$ & $(-0.00)$ \\
Transnational contact & -0.037 & -0.113 & -0.005 & 0.013 & -0.015 \\
& $(-0.91)$ & $(-1.56)$ & $(-0.12)$ & $(0.24)$ & $(-0.28)$ \\
Adjusted R2 & 0.029 & 0.148 & 0.056 & 0.012 & 0.026 \\
Mode/3 & 0.014 & 0.019 & 0.018 & -0.009 & 0.002 \\
Expatriate experience & $(0.70)$ & $(0.51)$ & $(1.00)$ & $(-0.32)$ & $(0.07)$ \\
& -0.042 & -0.123 & -0.005 & 0.016 & -0.022 \\
Transnational contact & $(-1.05)$ & $(-1.70)$ & $(-0.14)$ & $(0.30)$ & $(-0.42)$ \\
Supranational identity & $0.166^{* *}$ & $0.268^{*}$ & -0.075 & 0.100 & 0.150 \\
& $(2.68)$ & $(2.30)$ & $(-1.40)$ & $(0.080)$ & $(1.81)$ \\
\hline Adjusted R $R^{2}$ & 0.044 & 0.160 & 0.100 & 0.013 & 0.036 \\
\hline
\end{tabular}

Notes: OLS regressions, $\mathrm{t}$ statistics in parentheses. The effects of the control variables are not reported.

Significances: ${ }^{*} p<0.05,{ }^{*} p<0.01,{ }^{*}{ }^{*} p<0.001, N=354$

\section{Discussion}

Our study is the first to empirically assess the alleged divide between elites from various fields of activity and the general population in their positions on a wide range of contested denationalization issues. Our results point to a significant elitemass attitudinal gap on several issues related directly to the further opening up of national borders to various types of exchange, such as people, goods or economic redistribution, even after controlling for differences in age, gender, place of residence, education and political orientation. The elite-mass opinion incongruence on European integration observed in previous studies is thus part of a broader ideological gap that puts societal leaders and the general population on opposing sides with regard to issues related to the growing permeability of national borders.

Our study can therefore push forward the debate on the rise of a new globalization cleavage: denationalization issues not only polarize public opinion into groups of losers and winners (Teney et al. 2013) but also create a severe divide between the general population and elites. In line with the arguments of Schimmelfennig (2001) and Calhoun (2003), our results suggest that support for further opening up national borders can be considered part of the dominant ideology supported by the elites, who hold relatively uniform positive attitudes to- ward denationalization issues. Moreover, political elites do not differ strongly from the other elites in our sample in their almost unlimited support for denationalization. Such a lack of representation can present a serious challenge for Western European democracies, in fact it is often cited as one of the sources of citizens' increasing political disaffection and the rise of successful populist radical-right parties in Western European democracies.

This elite-mass attitudinal divide on denationalization is, however, likely to be more salient in Germany than in other Western European countries. Indeed, the reinvention of German identity after the WWII trauma has been explicitly directed toward European and international components. Germany's responsibility toward countries that suffered from WWII, for instance, is a core component in the supportive discourse of German elites regarding the European integration project (Diez Medrano 2003). The normative pressure on elites to fit a cosmopolitan ideal is therefore likely to be much stronger in Germany than in other European countries. Assessing similar elite-mass divides on denationalization in other Western European countries will help to shed light on the specificities of the German case.

Although we could empirically confirm the elitemass gap on a wide range of denationalization issues, our findings regarding a potential divide among elites on these issues are mixed. Firstly, the 
fields of activity do not have any strong polarizing effect among elites on contested denationalization issues. Our results therefore do not provide any evidence to support the postrecruitment hypothesis of Putnam (1976): elites from the eleven fields of activity hold rather consensual positions on denationalization issues that do not reflect the conflicting interests of their respective fields. Secondly, transnational practices, such as transnational contacts and mobility, are not significantly associated with denationalization issues. Previous studies based on mass survey data pointed to a consistent and significant role of transnational practices in explaining support for denationalization issues, such as European integration or the opening up of borders to immigrants. By contrast, our study is the first one to closely investigate this relationship among top positional elites (see also Helbling \& Teney 2014).

Our contrasting findings help to refine our understanding of the role of transnational practices in shaping positions on denationalization issues since this effect cannot be generalized to apply to societal leaders. The fact that transnational practices are not significantly associated with denationalization issues among elites might be due to a ceiling effect (Kuhn 2012). Accordingly, transnational practices might be significantly related to attitudes on denationalization issues up to a certain point. Once individuals hold regular transnational practices, this effect might become insignificant. Even if our transnational practices variables showed sufficient variation, elites would on average be much more likely than the general population to have spent some months abroad and to have regular contacts with many people living abroad.

Another explanation might be found in the types of transnational contacts: it might matter whether transnational practices are based on voluntary leisure activities or on professional obligations. Transnational practices investigated among the general population might on average be a result of leisure activities (such as holiday travel), while transnational practices reported by top positional elites might be mainly related to professional obligations (Helbling \& Teney 2014). Unfortunately, the data do not allow us to further investigate this hypothesis since elites were not asked to specify the main reason behind their transnational practices.

Unlike the general population, elites might hold stable and consistent positions that are not so easily affected by external events such as transnational practices. According to Converse (1964), mass attitudes are overall characterized by large volatility, incoherence and inconsistency, whereas elites tend to have stable, consistent and coherent attitudes. Accordingly, then, external events such as experiencing expatriate life or being in contact with people abroad might significantly affect the instable attitudes of the general population, but not the already anchored positions of elites. These striking results among elites open new research questions for transnational studies to better grasp the role of transnational practices in shaping attitudes across different social groups.

Finally, we investigated the role of supranational identification for elites' positions on denationalization issues. Our findings indicate that elites with a strong supranational identity are significantly more in favor of opening up borders to immigrants and for increasing aid to developing countries. However, supranational identity is significantly associated neither with attitudes toward international trade nor with satisfaction with the work of the EU and UN. These contrasting results enable us to push forward the debate on the role of collective identities in shaping attitudes toward the opening up of national borders: supranational identification plays a significant role on issues related to "moral cosmopolitanism" (Pogge 1992) but not on denationalization issues referring to neo-liberalism or satisfaction with supranational political regimes. Thus, a strong sense of belonging to a supranational entity is significantly linked to a sense of moral obligation toward human beings beyond the national community, as reflected by the immigration and development aid issues. By contrast, denationalization issues unrelated to any concern of global justice remain unaffected by supranational identity. Our analysis of the role of supranational identification thus highlights an important empirical distinction between cosmopolitan issues with a normative component of global justice on the one hand and, on the other hand, issues without any concern for moral values of justice, referred to as globalism (De Wilde \& Zürn forthcoming).

\section{References}

Azmanova, A., 2011: After the Left-Right (Dis)Continuum: Globalization and the Remaking of Europe's Ideological Geography. International Political Sociology 5: 384-407.

Best, H., 2012: Elite Foundations of European Integration: A Causal Analysis. Pp. 208-233 in: H. Best, H., G. Lengyel \& L. Verzichelli, The Europe of Elites: A Study into the Europeanness of Europe's Political and Economic Elites. Oxford: Oxford University Press. 
Bürklin, W. \& H. Rebenstorf, 1997: Eliten in Deutschland. Rekrutierung Und Integration. Opladen: Leske + Budrich.

Bunselmeyer, E., M. Holland Cunz \& K. Dribbisch, 2013: Projektbericht „Entscheidungsträger in Deutschland: Werte und Einstellungen“. Discussion Paper P 2013 001. Berlin: WZB.

Calhoun, C., 2002: The Class Consciousness of Frequent Travelers: Toward a Critique of Actually Existing Cosmopolitanism. South Atlantic Quarterly 101: 869-897.

Calhoun, C., 2003: "Belonging" in the Cosmopolitan Imaginary. Ethnicities 3: 531-553.

Converse, P.E., 1964: The Nature of Belief Systems in Mass Publics. Pp. 206-261 in: D. Apter (ed.), Ideology and Discontent. New York: Free Press.

Crouch, C., 2004: Post-Democracy. Cambridge: Polity.

De Wilde, P. \& H.-J. Trenz, 2012: Denouncing European Integration: Euroscepticism as Polity Contestation. European Journal Of Social Theory 15: 537-554.

De Wilde, P. \& M. Zürn, forthcoming: Debating Globalization: Cosmopolitanism and Communitarianism as Political Ideologies.

Diez Medrano, J., 2003: Framing Europe: Attitudes to European Integration in Germany, Spain, and the United Kingdom. Princeton: Princeton University Press.

Diez Medrano, J., 2010: A New Society in the Making. European Integration and European Social Groups. KFG Working Paper 12: 1-31. Freie Universität Berlin.

Ecker-Ehrhardt, M., W. Merkel, B. Wessels \& M. Zürn, 2008: Denationalisierung von Problemwahrnehmung. Repräsentative Bevölkerungsumfrage. Berlin: WZB.

Fligstein, N., 2008: Euro-Clash. The EU, European Identity, and the Future of Europe. Oxford: Oxford University Press.

Flockhart, T., 2005: Critical Junctures and Social Identity Theory: Explaining the Gap between Danish Mass and Elite Attitudes to Europeanization. Journal of Common Market Studies 43: 251-271.

Gustafson, P., 2009: More Cosmopolitan, No Less Local. European Societies 11: 25-47.

Hanquinet, L. \& M. Savage, 2011: The Europeanisation of Everyday Life: Cross-Border Practices and Transnational Identifications among $\mathrm{Eu}$ and Third-Country Citizens. Operationalisation of European Identity, Cosmopolitanism and Cross-Border Practices. EUCROSS Working Paper (2). http://www.eucross.eu/cms/index. php?option=com_content $\&$ view=category \&layout=blog \&id=10\&Itemid $=110$

Helbling, M. \& C. Teney, 2014: The Cosmopolitan Elite in Germany. Transnationalism and Postmaterialism. Global Networks (in press).

Hoffmann-Lange, U. 1992. Eliten, Macht und Konflikt in der Bundesrepublik. Opladen: Leske + Budrich.

Hoffmann-Lange, U., 2008: Studying Elite vs. Mass Opinion. Pp. 53-63 in: W. Donsbach \& M. Traugott (eds.), The Sage Handbook of Public Opinion Research. London: Sage.

Holsti, O.R., 2004: Public Opinion and American Foreign Policy. Ann Arbor: University of Michigan Press.
Hooghe, L., 2003: Europe Divided? European Union Politics 4: 281-304.

Hooghe, L., G. Marks \& C.J. Wilson, 2004: Does Left/ Right Structure Party Positions on European Integration? Pp. 120-140 in: G. Marks \& M. Steenbergen (eds.), European Integration and Political Conflict. Cambridge: Cambridge University Press.

Ignazi, P., 1992: The Silent Counter-Revolution. European Journal of Political Research 22: 3-34.

Jackman, S. \& L. Vavreck, 2011: Cosmopolitanism. Pp. 70-96 in: P.M. Sniderman \& B. Highton (eds.), Facing the Challenge of Democracy: Explorations in the Analysis of Public Opinion and Political Participation. Princeton, Princeton University Press.

Kaina, V., 1997: Wertorientierungen Im Eliten-Bevölkerungsvergleich: Vertikale Distanzen, Geteilte Loyalitäten Und Das Erbe Der Trennung. Pp. 351-390 in: W. Bürklin \& H. Rebenstorf (eds.), Eliten in Deutschland. Rekrutierung Und Integration. Opladen: Leske + Budrich.

Kendall, G., Z. Skrbis \& I. Woodward, 2009: The Sociology of Cosmopolitanism. Basingstoke: Palgrave Macmillan.

Kriesi, H., E. Grande, M. Dolezal, M. Helbling, D. Hoeglinger \& S. Hutter, 2012: Political Conflict in Western Europe. Cambridge: Cambridge University Press.

Kriesi, H., E. Grande, R. Lachat, M. Dolezal, S. Bornschier \& T. Frey, 2008: West European Politics in the Age of Globalization. Cambridge: Cambridge University Press.

Kuhn, T., 2011: Individual Transnationalism, Globalisation and Euroscepticism: An Empirical Test of Deutsch's Transactionalist Theory. European Journal of Political Research 50: 811-837.

Kuhn, T., 2012: Why Educational Exchange Programmes Miss Their Mark: Cross-Border Mobility, Education and European Identity. Journal of Common Market Studies 50: 994-1010.

Kühne, P., 2000: The Federal Republic of Germany: Ambivalent Promotion of Immigrants' Interests. Pp. 39-64 in: R. Penninx \& J. Roosblad (eds.), Trade Unions, Immigration and Immigrants in Europe 1960-1993. A Comparative Study of the Actions of Trade Unions in Seven West European Countries. New York: Berghahn.

Machatzke, J., 1997: Die Potsdamer Elitestudie. Positionsauswahl und Auschöpfung. Pp. 35-68 in: W. Bürklin $\&$ H. Rebenstorf (eds.), Eliten in Deutschland. Opladen: Leske+Budrich.

Mattila, M. \& T. Raunio, 2006: Cautious Voters - Supportive Parties: Opinion Congruence between Voters and Parties on the Eu Dimension. European Union Politics 7: 427-449.

Mau, S., J.A.N. Mewes \& A.N.N. Zimmermann, 2008: Cosmopolitan Attitudes through Transnational Social Practices? Global Networks 8: 1-24.

McAllister, I., 1991: Party Elites, Voters and Political Attitudes: Testing Three Explanations for Mass-Elite Differences. Canadian Journal of Political Science/Revue canadienne de science politique 24: 237-268.

McClosky, H. \& A. Brill, 1983: Dimensions of Tolerance. 
What Americans Believe About Civil Liberties. New York: Sage Foundation.

Molenaar, I.W. \& K. Sijtsma, 2000: User's Manual. Msp5 for Windows. A Program for Mokken Scale Analysis for Polytomous Items. Groningen: ProGAMMA.

Mudde, C., 2004: The Populist Zeitgeist. Government \& Opposition 39: 541-563.

Müller, W., M. Jenny \& A. Ecker, 2012: The Elites-Masses Gap in European Integration. Pp. 167-191 in: H. Best, G. Lengyel \& L. Verzichelli (eds.), The Europe of Elites. A Study into the Europeanness of Europe's Political and Economic Elites. Oxford: Oxford University Press.

Norris, P. \& R. Inglehart, 2009: Cosmopolitan Communications. Cultural Diversity in a Globalized World. Cambridge: Cambridge University Press.

Phillips, T., 2002: Imagined Communities and Self-Identity: An Exploratory Quantitative Analysis. Sociology 36: 597-617.

Pichler, F., 2009a: Cosmopolitan Europe. European Societies 11: 3-24.

Pichler, F., 2009b: 'Down-to-Earth' Cosmopolitanism Subjective and Objective Measurements of Cosmopolitanism in Survey Research. Current Sociology 57: 704732 .
Pichler, F., 2012: Cosmopolitanism in a Global Perspective: An International Comparison of Open-Minded Orientations and Identity in Relation to Globalization. International Sociology 27: 21-50.

Pogge, T.W., 1992: Cosmopolitanism and Sovereignty. Ethics 103: 48-75.

Putnam, R.D., 1976: The Comparative Study of Political Elites. Englewood: Prentice Hall.

Schimmelfennig, F., 2001: The Community Trap: Liberal Norms, Rhetorical Action, and the Eastern Enlargement of the European Union. International Organization 55: 47-80.

Steenbergen, M.R., E.E. Edwards \& C.E. de Vries, 2007: Who Is Cueing Whom?: Mass-Elite Linkages and the Future of European Integration. European Union Politics 8: 13-35.

Suvarierol, S., 2011: Everyday Cosmopolitanism in the European Commission. Journal of European Public Policy 18: 181-200.

Teney, C., O. Lacewell \& P. de Wilde, 2013: Winners and Losers of Globalization in Europe. Attitudes and Ideologies. European Political Science Review. DOI: 10.1017/S1755773913000246.

Zürn, M., 1998: Regieren Jenseits des Nationalstaates. Frankfurt a.M.: Suhrkamp.

\section{Autorenvorstellung}

Céline Teney, geb. 1981 in Belgien. Studium der Soziologie und Ethnologie in Freiburg. Promotion in Brüssel. Von 2010 bis 2014 wissenschaftliche Mitarbeiterin im Brückenprojekt „Die politische Soziologie des Kosmopolitismus und des Kommunitarismus“ am Wissenschaftszentrum Berlin für Sozialforschung. Seit 2014 Leiterin der Nachwuchsgruppe „Winners of Globalization? A Study on the Emergence of a Transnational Professional Elite in Europe“ an der Universität Bremen.

Forschungsschwerpunkte: Migrationssoziologie, Soziologie der EU, Politische Soziologie.

Wichtigste Publikationen: Winners and Losers of Globalization in Europe. Attitudes and Ideologies (mit O. Lacewell \& P. de Wilde), European Political Science Review 2013; High Political Participation, High Social Capital? A Relational Analysis of Youth Social Capital and Political Participation (mit L. Hanquinet) Social Science Research 41, 2012; zuletzt in dieser Zeitschrift: Space matters. The group threat hypothesis revisited with geographically weighted regression. The case of the NPD 2009 electoral success, ZfS 41, 2012: 207-226.

Marc Helbling, geb. 1977 in der Schweiz. Studium der Politikwissenschaft in Lausanne und Paris. Promotion in Zürich. Von 2009 bis 2011 wissenschaftlicher Mitarbeiter am Wissenschaftszentrum Berlin für Sozialforschung. Seit 2011 Leiter der Emmy-Noether Gruppe „Immigration Policies in Comparison“ (IMPIC) am WZB. Gastforscher und -dozent u. a. in Princeton, Harvard, New York, Oxford und am Europäischen Hochschulinstitut in Florenz.

Forschungsschwerpunkte: Staatsbürgerschafts- und Immigrationspolitik, Fremdenfeindlichkeit/Islamophobie.

Wichtigste Publikationen: „Opposing Muslims and the Muslim Headscarf in Western Europe“, European Sociological Review 2014; Political Conflicts in Western Europe, (mit H. Kriesi et al.), Cambridge 2012; Practising Citizenship and Heterogeneous Nationhood. Naturalisations in Swiss Municipalities, Amsterdam 2008; „Political Mobilizing, Cultural Diversity and Social Cohesion“, (mit T. Reeskens \& D. Stolle), Political Studies 2014. 